\title{
European hotel industry performance 2007
}

Received (in revised form): 17 March 2008

\section{Elana Bader}

is an associate with the London office of HVS, specialists in hotel valuation and consultancy in Europe, the Middle East and Africa. She joined the firm in September 2005 after completing a BSc in hotel administration at Cornell University.

\section{Elke Geieregger}

is an associate with the London office of HVS. She holds a BA (Hons) in tourism management and is a part-qualified member of the Chartered Institute of Management Accountants (CIMA).

\section{Cristina Balekjian}

is a market intelligence analyst with the London office of HVS. Cristina holds a BSc (Hons) in International Hospitality and Tourism Management.

\begin{abstract}
As part of our series of quarterly papers, which aim to observe the latest trends in key hotel industry sectors, this edition presents a snapshot of current trends in the market concerning values, acquisitions and disposals, as well as funding and development. The snapshot is drawn from two of HVS's core annual articles. HVS's European Hotel Valuation Index (written by Elana Bader) is an annual review of European hotel value trends. The survey shows that hotel values achieved a fourth consecutive year of growth, increasing by 2.6 per cent in 2007 , compared with an increase of 9.0 per cent in 2006. Values per room largely exceed the peak values of 2000. HVS's European Hotel Transaction Review (written by Cristina Balekjian and Elke Geieregger) analyses the single asset and portfolio hotel transactions that shaped 2007. The review highlights the increase in the volume of portfolio transactions and analyses the impact of the economic slowdown on hotel investment. After going into 'orbit' and achieving record levels of investment in 2006, 2007 maintained high levels of investment, demonstrating a slowdown towards the end of the year as we "weather the storm' of the credit crunch.
\end{abstract}

\section{Keywords:}

European RevPAR, hotel values, hotel investment activity, hotel yield trends

Elana Bader HVS - London Office 7-10 Chandos Street London $\mathrm{W}_{1} \mathrm{G} 9 \mathrm{DQ}$, UK Tel: 02078787710 Fax: 02078787799 E-mail: ebader@hvs.com
Journal of Retail and Leisure Property (2008) 7, 179-185. doi:10.1057/rlp.2008.15; published online 18 June 2008

\section{INTRODUCTION}

The London office of HVS annually publishes the European Hotel Valuation Index (HVI) and the European Hotel Transactions Survey. 


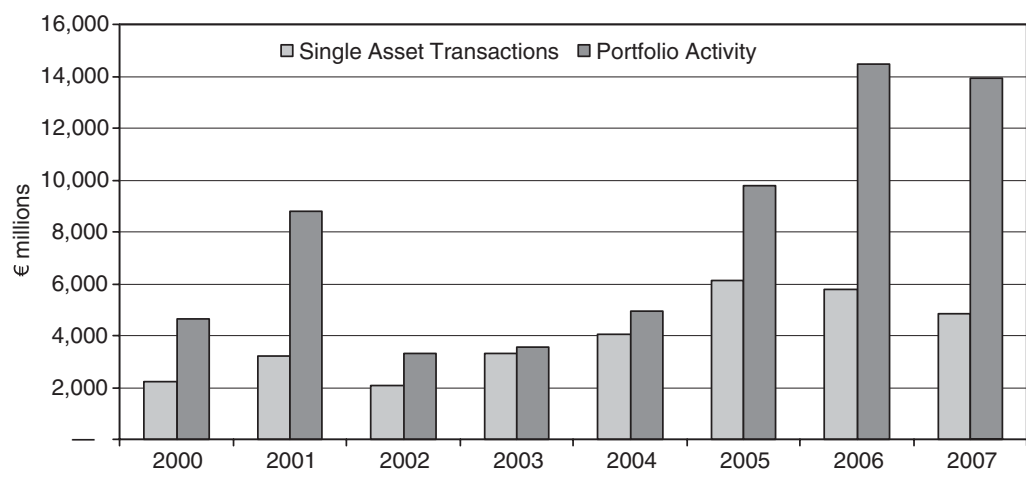

Figure I: Total European hotel investment volumes 2000-07 (€ millions)'

The former monitors annual trends in the values of, mainly, four-star and five-star hotels in 34 major European markets. Additionally, it ranks each market relative to a European average and reports the average value per room. The latter records all single asset and portfolio transactions in Europe above $€ 7.5 \mathrm{~m}$, the minimum amount set for a transaction to qualify for inclusion in our survey, and provides buyer profiles for both single asset and portfolio transactions.

2007 will be remembered for being the year of compressed yields, cheaply available debt, large portfolio divestments and the two-pound dollar. It also continued to showcase the momentum of the European hotel market, even with the inclusion of additional eastern European markets; the average value per room in Europe is at its highest level in the 15 years recorded by the HVI. The top five most expensive European cities in which to buy a hotel remain many of the same players as previous years. Our analysis of values per room in euro shows that London remains at the top at $€ 623,400$, followed closely by Paris at $€ 601,700$. Tallinn is at the bottom of the table at $€ 129,100$, with Riga not far away at $€ 132,500$.

As shown in Figure 1, after a record year in 2006 in terms of the volume of hotel investment, activity in the European hotel market fell back to just under $€ 19 \mathrm{bn}$ in 2007 . This decline, albeit only slight, equates to a drop of approximately $€ 1.5 \mathrm{bn}$, or 7 per cent.

Until the subprime crisis in the USA began in the third quarter of the year, a crisis which in Europe became known colloquially as the "credit crunch', the market was continuing to power ahead. There were several major portfolio deals, such as the disposal by Hilton of the Scandic portfolio, two sale-and-leaseback deals by Accor and the sale of Alliance Hospitality. Yet again, the Hilton portfolio featured prominently in the total volume of investment, with the purchase in June of Hilton Hotels Corporation's portfolio by private equity company The Blackstone Group for a total of approximately $€ 19 \mathrm{bn}$. This transaction involved Hilton's worldwide portfolio.

In contrast to 2006, 2007 saw an increase in large-scale investment made by private equity funds, as hotel operators continued to divest their assets in order to become more asset-light, and thus undertook sale-and- 


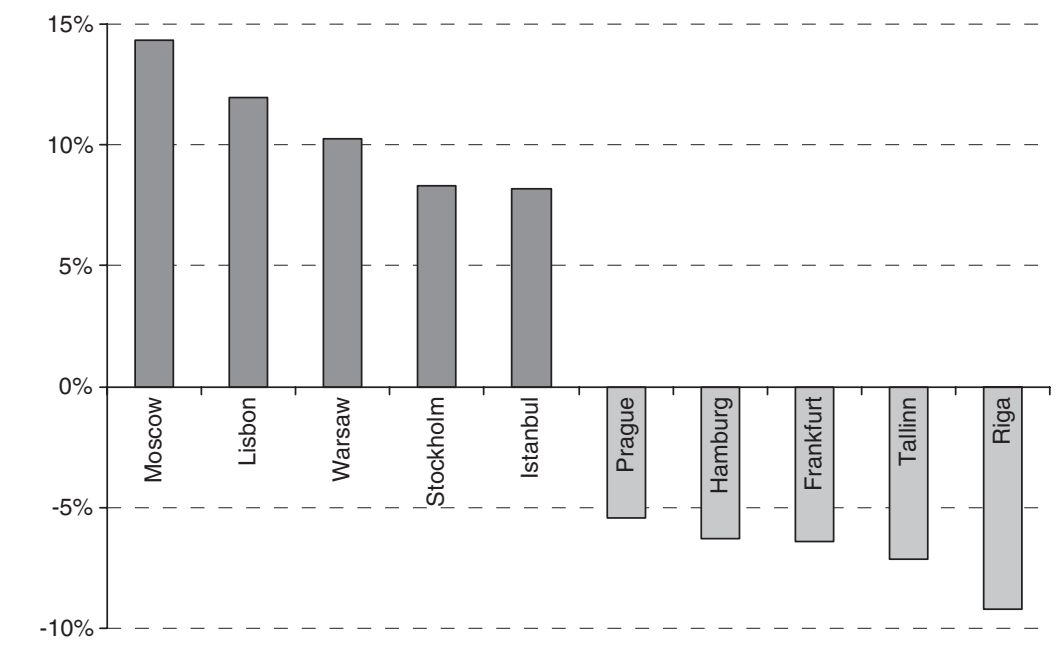

Figure 2: Top and bottom five 2007 — percentage change in hotel value per room ${ }^{2}$

leaseback or sale-and-manageback transactions. As a result of such agreements, hotel operators gain a considerable sum of capital that can be put towards refurbishment or be used to fund acquisition and development activity in new markets or brands. Another trend that has become more evident is that investors have recently started to turn to alternative hotel investments, focusing on other hotel segments as luxury assets become scarcer and the availability of such properties becomes more limited. The number of transactions involving the budget and midmarket segments grew in 2007.

\section{HOTEL VALUES}

Average hotel values, expressed in euro, achieved a fourth consecutive year of growth in 2007 at 2.6 per cent (in excess of Eurozone inflation) compared to 9.0 per cent in 2006. The European average continues to be led by the dominant primary markets, particularly London, Paris, Zürich and Geneva, with Moscow's consistently strong growth also contributing significantly. While 18 of the 34 cities reviewed experienced growth in excess of Eurozone inflation, the remaining markets (with the exceptions of Edinburgh and Copenhagen), however, experienced declines in value; these declines have contributed to the slowdown in average value growth in Europe.

Nonetheless, values per room largely exceed the peak values of 2000 (Madrid, Barcelona, Warsaw, Hamburg and Frankfurt are the exceptions). Values in the newly included markets of Zagreb, Belgrade, Riga and Tallinn have dropped below their peak values of 2006.

Figure 2 shows that in 2007, for the fourth time in the last five years, Moscow had the greatest percentage growth in value, at 14.3 per cent.

Values per room in Lisbon grew by 11.9 per cent to $€ 167,200$, the second strongest percentage value growth in 2007 and also the second consecutive year of strong value growth for the city. 


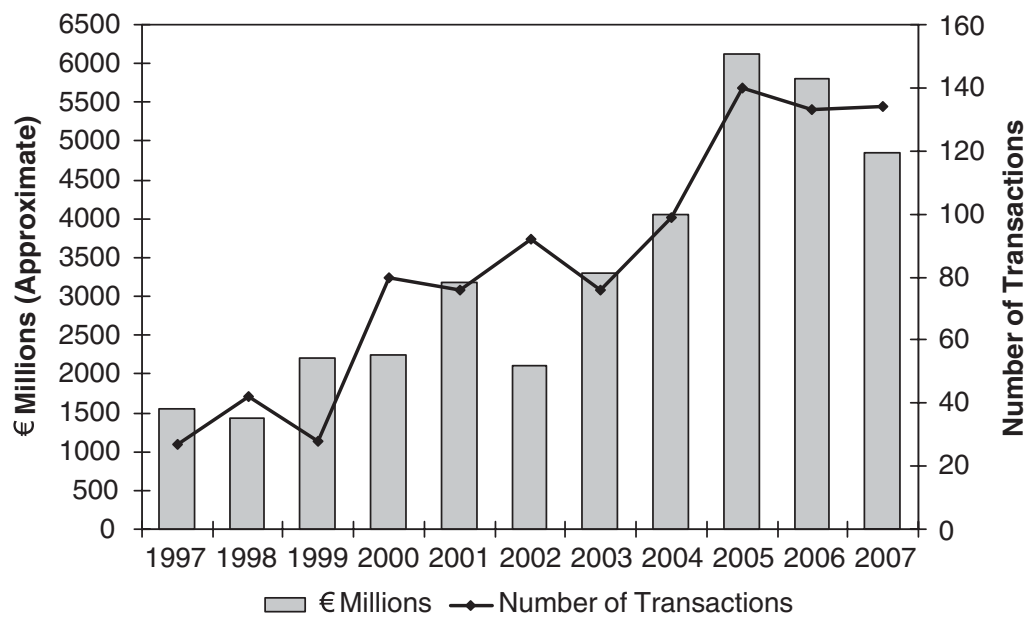

Figure 3: European single asset transactions 1997-2007³

Warsaw, which has been dealing with its previous problems of oversupply, has experienced the third strongest value growth at 10.2 per cent, resulting in a value of $€ 208,800$ per room, overtaking markets such as Birmingham, Bratislava, Hamburg and Budapest.

The top four most expensive cities in which to acquire a hotel room remain broadly similar. London retains the number one spot in our value per room rankings, having surpassed the $€ 600,000$ mark in 2007 to reach $€ 623,400$, an increase of 5.5 per cent. Values per room in Paris have also exceeded the $€ 600,000$ mark, reaching $€ 601,700$. The French capital experienced the tenth strongest value growth in 2007 at 6.0 per cent to narrow the gap on London's value per room. Moscow jumps to third place, having overtaken Rome, reaching $€ 491,300$ per room, which is more than double the city's value per room in 2003. Rome had the sixth lowest value growth, dropping by 4.3 per cent to $€ 453,500$ per room.

While Zürich remains in sixth place, after Milan, its value per room is quickly closing the gap on the fashionable Italian city; values grew by 7.6 per cent to reach $€ 412,900$ per room. Istanbul's growing popularity, showcased by growth of 8.2 per cent (the fifth highest), has meant that values have exceeded $€ 300,000$ for the first time to reach $€ 311,900$, which remains above the European average for the third consecutive year. On the other side of the table, Tallinn $(€ 129,100)$ and Riga $(€ 132,500)$ have both dropped to the last two places in the rankings, while Lisbon (€167,200), Hamburg (€192,000), Berlin (€174,900) and Frankfurt $(€ 168,300)$ remain among the poorest performing western European markets.

\section{HOTEL ACQUISITIONS AND DISPOSALS}

As shown in Figure 3, in 2007 HVS recorded a total of 117 transactions involving single hotel assets, each of more than $€ 7.5 \mathrm{~m}$. In general, there 
was a decrease of 13 per cent in the number of transactions in 2007 (the number of transactions in 2006 was 134). This decrease was due mostly to the shift in investment from single assets to portfolios. There was also a slowdown in investment in the second half of the year. The average transaction price of $€ 234,000$ per room remained in line with 2006, showing a slight decrease. In 2006, the growth in the number of trophy assets transacted greatly increased the sales price per room, with hotels such as the Four Seasons Hotel Milan and Hotel Arts Barcelona selling for $€ 1.7 \mathrm{~m}$ and $€ 863,000$ per room, respectively. Meanwhile, the trend in single asset activity in 2007 was for fewer trophy asset investments with sales prices of more than $€ 800,000$ a room.

Portfolio transactions were the strongest driver of total investment volume in Europe in 2007, as they had been in 2006. HVS estimates the total volume of investment in European hotel portfolios in 2007 to have been approximately $€ 14 \mathrm{bn}$. This total is only marginally below the record volume of $€ 14.5$ bn recorded in 2006.

One of the highest values per room in 2007 was achieved by Amberley Castle in Arundel, in the English county of West Sussex. Von Essen Hotels acquired the 14th-century fortress for $€ 17.7 \mathrm{~m}$, or $€ 934,000$ per room, with a view to including it in its 25 strong chain of boutique hotels.

\section{FUNDING AND DEVELOPMENT}

European hotel assets continue to attract investors from all over the world. In the first half of the year, cross-border deals continued to be facilitated by the euro, as it allowed greater transparency and increased the pool of potential lenders and investors seeking to invest in European markets.

In 2007, investor profiles were different again; private equity companies appeared at the top of the list with a share of 44 per cent of the total transaction activity. It should, however, be noted that The Blackstone Group transaction accounted for 5 per cent of the total portfolio activity and a notable 4 per cent of the total investment volume in Europe in 2007. As The Blackstone Group is a private equity company, such activity resulted in the increased presence of private equity companies as an investor type. Private equity groups acquired assets worth €9bn in 2007, compared to just over $€ 5$ bn the previous year. We note that the total investment value of the Hilton Hotels Corporation portfolio relates to traded European assets only.

Asset ownership in Europe has primarily been dominated by European hotel companies. As capital becomes more readily available in locations such as the middle east, including Israel, this trend is likely to continue changing, and we expect to see even more middle eastern investors (such as MBI International, the buyers of The Eton Collection in the UK) and Israeli investors (such as Jelmoli Holding, which acquired the portfolio of Seiler Hotels) trading hotel assets in Europe. The emergence of eastern European investors is another trend likely to become commonplace in the future, as interest in the sector rises and investment in the region increases. Examples of transactions made by such investors include the 
acquisition by Russian real estate and construction company Mirax Group of the Sungate Port Royal Hotel in Turkey for $€ 250 \mathrm{~m}$.

\section{CONCLUSIONS AND OUTLOOK}

With the benefit of hindsight, it is now clear that mid-2007 marked the turning point in the European hotel investment market cycle, with the previous 18 months representing the peak in the market. It should be clearly noted and recognised that two cycles affect hotels. The first concerns hotel trading performance and the second the investment market and investor appetite. Although there is an overlap of and a correlation between these two cycles, unlike in previous downturns hotel trading performance is for the most part continuing to improve, albeit at much more subdued levels than in recent years. In contrast, it is the meltdown in the debt financing markets that has caused the investment market cycle to go 'over the top' and cause a decline in hotel values, rather than a collapse in trading performance precipitating the fall.

Average European values per hotel room in 2007 continued growing to another year of record values. Strong growth in markets such as London, Paris, Moscow and Zürich continues to pull the average upwards, albeit at a slower rate than in the previous two years. Investors continued to develop their interests in eastern Europe, and competitive debt markets, particularly in the first half of the year, tended to assist the growth in average values. The emergence of the 'credit crunch' around August 2007 has since destabilised the market and has played a part in some markets' declines in value by the end of 2007; had we published an edition of the HVI in mid-2007 the values reported would in all likelihood have been higher than they were by the year end. Lenders in particular are more cautious and some have stopped lending to new customers. Overall, projects at the moment are proving more difficult to finance, and debt is certainly more expensive. This has slowed down development growth and discouraged buyers to some extent, resulting in fewer transactions in the latter part of last year. Investors and operators now have the opportunity to look at business optimisation and efficiency in the form of better cost control and streamlining, and also to better determine the trajectories of supply and demand trends across Europe.

In 2008 we expect values in general to level out in the first half of the year before gaining momentum closer to 2009. The potential for development in some western European markets will have dried up to some extent, except for mixed-use and budget hotels, but the interest of international investors, developers and operators in Central and eastern Europe, Russia and Kazakhstan will continue to grow. We consider that upcoming markets will include Croatia, Turkey, the Black Sea states, provincial Russia and Kazakhstan.

In addition, we generally expect that the first half of 2008 will see a slowdown in the number of deals being completed, as many are currently postponed and investors have become cautious about the current environment. It is, however, expected that the market will start to make its recovery in mid-2008. Solutions to the credit crunch may be found so that once again we may be able to see a stabilisation of interest 
rates and an increase in hotel property values and in the volume of hotel transactions.

(c) $2008 \mathrm{HVS}$

\section{Notes}

1. HVS's European Hotel Transactions 2007, Elke Geieregger, Cristina Balekjian and Karen Smith.

2. HVS's European Hotel Valuation Index 2008, Elana Bader and Dominique Bourdais.

3. HVS's European Hotel Transactions 2007, Elke Geieregger, Cristina Balekjian and Karen Smith. 